
\title{
ANALISIS FAKTOR FISIKA
PENYEBAB KERUSAKAN KOLEKSI CETAK
DI PERPUSTAKAAN UMUM KABUPATEN MALANG
}

胡

\author{
Eka Ratri Noor Wulandari ${ }^{1^{*}}$, Tri Mega Asri ${ }^{2}$, Muhammad Faris Naufal ${ }^{3}$ \\ 1,2,3 Program Pendidikan Vokasi, Universitas Brawijaya \\ *Korespondensi: ekaratri@ub.ac.id
}

Diajukan: 30-08-2019; Direview: 02-07-2019; Diterima: 08-03-2020; Direvisi: 20-03-2020

\begin{abstract}
The majority of library materials are in printed form. The printed collection generally made of cellulose paper which is influenced by various factors. The physical factor is a factor that affects the damage of library materials such as temperature, humidity, light, and dust. Public Library of Malang Regency is a library that has printed collection of more than 25.000 copies and most of it is in damaged condition. The damage in the collection such as dusty, moldy, and crumpled conditions. In this experiment, light and dust were observed in the library room and collection. Furthermore, temperature and humidity were measured by a thermohygrometer. Based on the experimental result obtained that dust attach both in collection and bookshelf. The source of light in the library comes from sunshine and lamp. The daily temperature average in this library is $27.4^{\circ} \mathrm{C}$ and the humidity is $65 \% \mathrm{RH}$. This value is higher than the required condition which is temperature of $19^{\circ} \mathrm{C}-23^{\circ} \mathrm{C}$ and humidity of $40-50 \% \mathrm{RH}$.
\end{abstract}

\begin{abstract}
ABSTRAK
Mayoritas koleksi bahan pustaka umumnya berbentuk cetak. Koleksi cetak umumnya berbahan dasar kertas yang kondisinya akan dipengaruhi oleh berbagai macam faktor. Salah satu faktor yang berpengaruh terhadap kerusakan koleksi cetak adalah faktor fisika yang terdiri dari suhu, kelembaban, cahaya dan debu. Perpustakaan Umum Kabupaten Malang memiliki lebih dari 25.000 eksemplar koleksi cetak berupa buku dan banyak yang mengalami kerusakan. Kerusakan yang disebabkan oleh adanya pengaruh faktor fisika diantaranya adalah berdebu, berjamur, dan mengeriting. Pada penelitian ini, dilakukan pengamatan terhadap cahaya dan debu yang ada pada ruangan dan koleksi perpustakaan. Selain itu, dilakukan pengukuran suhu dan kelembaban menggunakan thermohygrometer. Dari hasil penelitian diketahui bahwa terdapat banyak debu yang menempel pada koleksi maupun rak penyimpan. Cahaya pada perpustakaan bersumber dari cahaya matahari dan lampu yang digunakan. Rata-rata suhu dan kelembaban harian yaitu $27,4^{\circ} \mathrm{C}$ dan $65 \% \mathrm{RH}$. Nilai ini lebih tinggi dari yang dipersyaratkan yaitu suhu sebesar $19^{\circ} \mathrm{C}-$ $23^{\circ} \mathrm{C}$ dan kelembaban antara $40-50 \%$ RH.
\end{abstract}

Keywords: Print collection; Public library; Physical factors; Temperature; Humidity

\section{PENDAHULUAN}

Perpustakaan merupakan salah satu unit kerja yang mempunyai tugas mengumpulkan, menyimpan dan memelihara koleksi/bahan pustaka dan sumber informasi lainnya yang dikelola secara sistematis sehingga dapat digunakan oleh pemakainya secara berkelanjutan. Menurut UU No.43 Tahun 2007 tentang perpustakaan, bahan pustaka merupakan semua hasil karya yang berbentuk karya tulis, karya cetak, dan karya rekam (bahan pustaka non-buku).

Permasalahan kerusakan koleksi yang sering terjadi di perpustakaan adalah kerusakan fisik koleksi, terutama yang terbuat dari bahan kertas. Hal tersebut disebabkan oleh lingkungan penyimpanan yang tidak memenuhi syarat dan penanganan yang salah terhadap bahan koleksi. Apalagi di Indonesia, yang memiliki iklim tropis sangat tidak mendukung bahan pustaka kertas untuk bertahan lama, terutama pada musim hujan (kelembaban udara 
menjadi relatif tinggi) dapat menyebabkan kekuatan kertas menjadi berkurang dan lemah (Razak, Anggraini, \& Supriyanto 1992).

Kerusakan bahan pustaka dapat disebabkan oleh faktor internal dan eksternal (Fatmawati, 2017). Faktor internal - kerusakan terjadi akibat bahan baku pembuatan kertas, dan faktor eksternal - kondisi lingkungan yang berpengaruh terhadap kerusakan bahan pustaka (Riyadi, 2014). Salah satu faktor eksternal yaitu faktor fisika. Faktor fisika merupakan salah satu faktor yang menjadi penyebab kerusakan pada bahan pustaka yang terdiri atas cahaya, udara/debu, suhu dan kelembaban (Martoatmodjo, 2014).

Suhu ruang koleksi perpustakaan sebaiknya diatur pada $19^{\circ}-23^{\circ} \mathrm{C}$ dengan kelembaban relatif ideal antara 40-50\%. Kondisi ruangan dengan kelembaban relatif tinggi menyebabkan ruang koleksi menjadi lembab. Kelembaban ruang koleksi disebabkan adanya sifat higroskopis (mudah menyerap air) dari kertas sehingga akan mempermudah tumbuhnya jamur pada koleksi. Selain itu, zat polutan yang masuk ke dalam gedung melalui ventilasi udara juga dapat menyebabkan kerusakan kertas koleksi. Polusi menghasilkan sulfur oksida dan nitrogen oksida yang dapat diserap oleh kertas sehingga membuat warna kertas menjadi coklat dan rapuh. Untuk mencegah terjadinya kerusakan fisik koleksi perpustakaan, perlu dilakukan tindakan preservasi.

Sebagaimana yang dilakukan oleh Perpustakaan Umum Kabupaten Malang, kegiatan preservasi dilakukan untuk mencegah terjadinya kerusakan koleksi yang disebabkan oleh faktor fisika. Perpustakaan ini memiliki koleksi yang terdiri dari buku teks, buku referensi, majalah, Koran, dan e-book. Jumlah koleksi cetak sekitar 25.949 eksemplar dengan 10.716 judul. Koleksi perpustakaan dicetak sekitar tahun 1900 - 2000, dan sampai saat koleksi yang rusak secara fisik sekitar 1.415 eksemplar. Penelitian ini membahas tentang analisis faktor fisika penyebab kerusakan koleksi cetak di Perpustakaan Umum Kabupaten Malang. Penelitian ini diharapkan dapat menjadi acuan petugas perpustakaan untuk preservasi koleksi perpustakaan sehingga dapat bertahan dalam jangka waktu yang lebih lama.

\section{TINJAUAN PUSTAKA}

Koleksi perpustakaan, khusunya buku terbuat dari bahan kertas - yang kondisinya dapat rusak karena faktor fisika atau faktor kimia. Penelitian ini fokus pada kerusakan kertas koleksi yang disebabkan faktor fisika. Sebelum membahas faktor fisika yang menyebabkan kerusakan kertas koleksi, dijelaskan terlebih dahulu sekilas tentang kertas.

Kertas dalam bahasa Inggris disebut paper, dan dalam bahasa Belanda disebut papier. Kertas merupakan bahan yang tipis dan rata, yang dihasilkan dengan kompresi serat yang berasal dari pulp. Pulp merupakan hasil pemisahan serat dari bahan baku berserat (kayu maupun non-kayu) melalui berbagai proses pembuatannya (mekanis, semikimia, dan kimia). Pulp terdiri dari serat-serat (selulosa dan hemiselulosa) sebagai bahan baku kertas (Bahri, 2015). Ukuran kekuatan kertas dapat dilihat melalui seberapa panjang rantai selulosa yang membentuk serat kertas. Tingkat keasaman $(p H)$ dapat menurun dengan adanya lingkungan yang buruk, seperti polusi dan kualitas udara yang rendah. Apabila rantai serat selulosa panjang terputus, akan terjadi pemutusan berkelanjutan dan reaksi hidrolisis yang akan meningkatkan produksi asam (Riyadi, 2014).

Ada beberapa penyebab kerusakan kertas yang bersumber dari faktor fisika, yaitu debu, suhu dan kelembaban, dan cahaya.

- Debu, merupakan salah satu partikel kecil yang terdapat dalam udara. Debu dapat masuk ke ruang perpustakaan melalui jendela, pintu, lubang angin, dan celah-celah kecil. Debu 
yang masuk ke perpustakaan dapat mengakibatkan kerusakan fisik koleksi dan mengakibatkan pencemaran udara (bentuk gas) yang menimbulkan keasaman pada kertas (Dureau \& Clements, 1990). Apabila debu menempel atau melekat pada kertas, maka akan terjadi reaksi kimia yang mengakibatkan tingginya tingkat keasaman pada kertas dan membuat kertas menjadi rapuh dan mudah rusak (Martoatmodjo, 2014).

- Suhu dan Kelembaban, mempunyai hubungan yang saling bergantung dan terbalik. Hampir seluruh bahan yang ada pada koleksi mempunyai sifat higroskopis. Perubahan kelembaban dan suhu yang sangat cepat dan fluktuatif dapat membuat perubahan karakter bahan koleksi, seperti fleksibilitas, kekuatan tarik, ukuran pori, dan kerapuhan. Adanya kelembaban relatif terlalu tinggi adalah kecenderungan tumbuhnya jamur pada kertas (Riyadi, 2014). Kelembaban udara yang terlalu tinggi atau terlalu rendah akan mempercepat pertumbuhan jamur dan serangga. Pada keadaan kelembaban yang terlalu tinggi akan menyebabakan tinta yang larut dalam air akan menyebar dan kertas pada buku akan saling menempel sehingga sulit dilepas pada saat kering. Sebaliknya jika kelembaban udara terlalu rendah, menyebabkan kertas menjadi kering (Alahudin, 2014). Suhu ruang koleksi perpustakaan sebaiknya diatur kelembabannya (antara $19^{\circ} \mathrm{C}-23^{\circ} \mathrm{C}$ ), untuk kelembaban relatif idealnya antara 40-50\%. Suhu dan kelembaban udara di negara tropis dapat diatur dengan pendingin ruangan/AC (Teygeler, et al, 2001).

- Cahaya, kerusakan koleksi karena cahaya sangat tergantung dari panjang gelombang dan waktu pencahayaan, semakin kecil panjang gelombang dan semakin lama waktu pencahayaan maka koleksi semakin cepat rusak (Soraya \& Damayanti, 2015). Ada dua macam cahaya yang digunakan untuk menerangi ruangan, yaitu cahaya alam (cahaya matahari) dan cahaya buatan (lampu - lampu pijar, lampu TL/PL/fluorescent) (Darmono, 2001). Cahaya dapat membuat kertas menjadi pucat dan tinta memudar dan kertas berubah menjadi kecoklatan. Cahaya tersebut akan mempercepat oksidasi dari molekul selulosa, sehingga rantai ikatan kimia pada molekul tersebut terputus (Makarim \& Ramdhan, 2014).

\section{METODE}

Penelitian dilakukan dengan cara mengamati dan mengukur kondisi faktor fisika di Perpustakaan Umum Kabupaten Malang. Faktor fisika khususnya suhu dan kelembaban, diamati dengan cara mengukur suhu dan kelembaban relatif dengan menggunakan alat ukur thermohygrometer (CV Java Multi Mandiri, 2019). Thermohygrometer digunakan untuk mengukur suhu dan kelembaban relatif secara bersamaan dan berkala (Gambar 1).

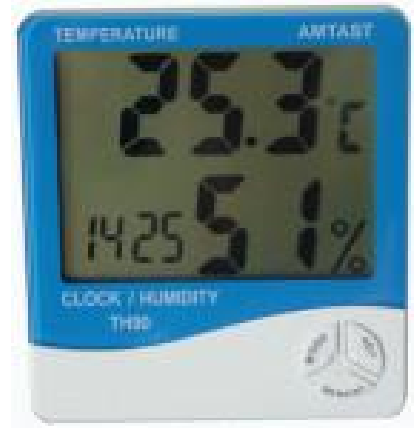

Gambar 1. Thermohygrometer 
Thermohygrometer akan mendeteksi suhu dengan satuan derajat celcius $\left({ }^{\circ} \mathrm{C}\right)$, dan mendeteksi kelembaban relatif dengan satuan persen (\%). Nilai yang ditunjukkan alat ini akan berubah sesuai dengan kondisi yang ada. Alat ini diletakkan di dalam ruang perpustakaan agar dapat mendeteksi suhu dan kelembaban secara berkala. Pengukuran suhu dan kelembaban dilakukan pada waktu pagi, siang, dan sore hari di ruang koleksi bacaan umum (Gambar 2).

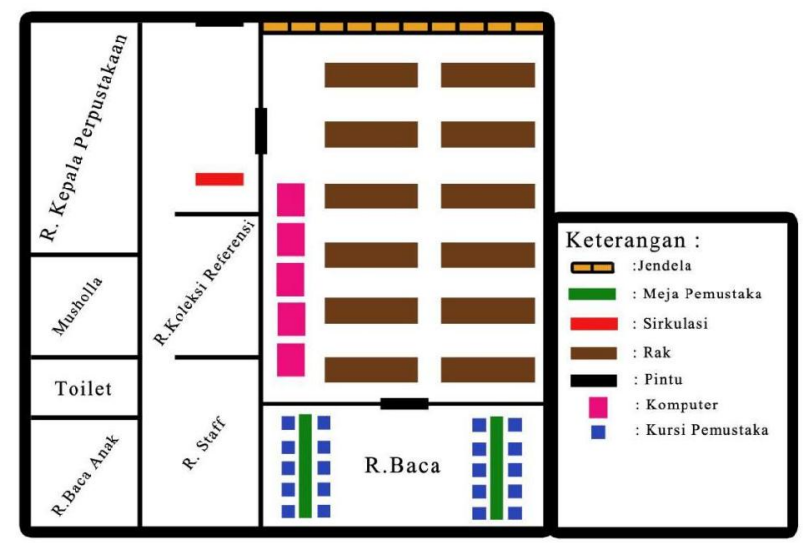

Gambar 2. Denah koleksi bacaan umum Perpustakaan Umum Kabupaten Malang

Pembacaan hasil pengukuran dilakukan setiap 5 menit. Hal ini dilakukan untuk mengetahui fluktuasi suhu dan kelembaban di ruangan koleksi bahan bacaan umum, yaitu ruang koleksi dan ruang baca. Cahaya dan debu diamati dengan hati-hati pada setiap koleksi.

\section{HASIL DAN PEMBAHASAN}

\subsection{Jenis Kerusakan Koleksi}

Koleksi bahan bacaan umum merupakan koleksi yang sering di pinjam oleh pemustaka, sehingga terdapat berbagai jenis kerusakan seperti koleksi yang sobek, koleksi yang terdapat coretan, koleksi yang ditumbuhi jamur, koleksi yang berdebu, koleksi yang rusak karena serangga, koleksi yang mengeriting, dan koleksi yang jilidannya terlepas (Gambar 3 - Gambar 8).

1) Koleksi yang sobek
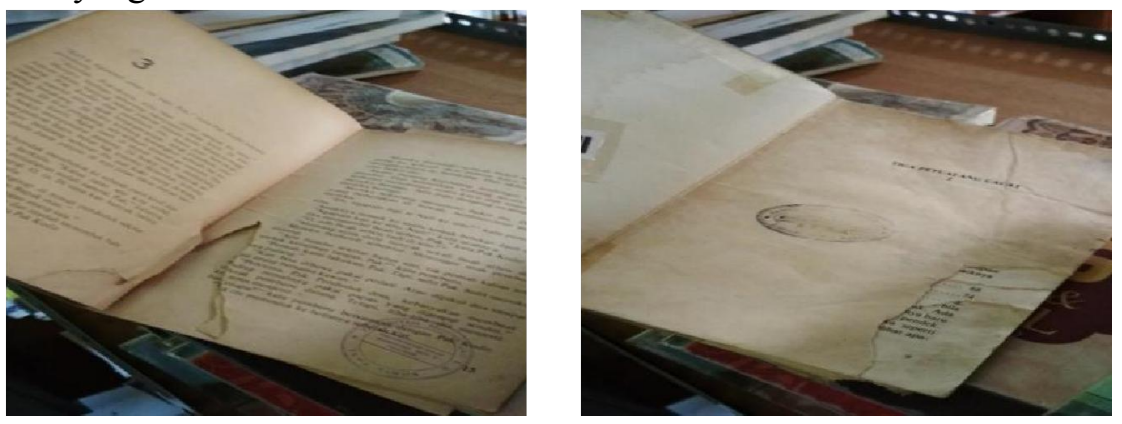

Gambar 3. Koleksi yang sobek

Koleksi sobek (terkoyak) disebabkan binatang pengerat, seperti tikus. Hal ini disebabkan kondisi ruang koleksi bahan bacaan umum yang kurang bersih, terutama di bagian pojok ruangan. 
2) Koleksi yang ditumbuhi jamur
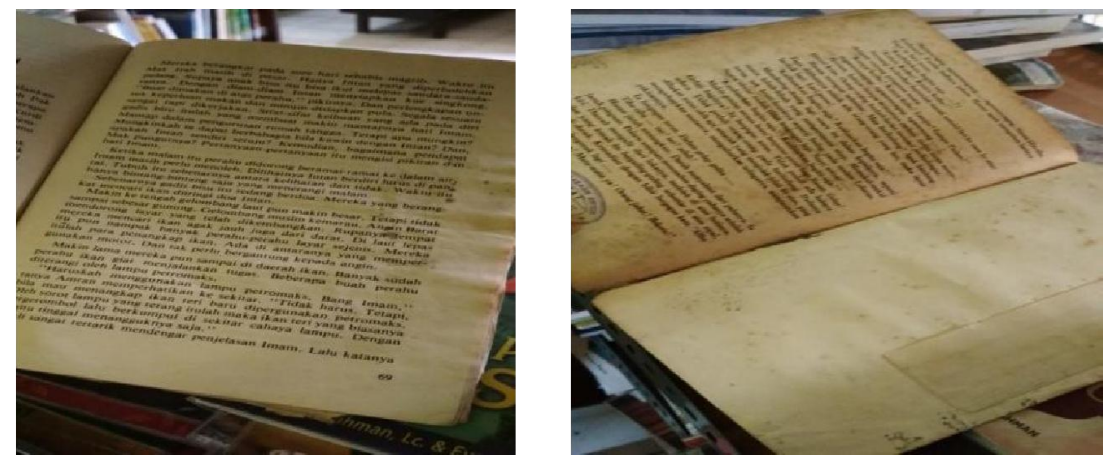

Gambar 4. Koleksi yang berjamur

Koleksi berjamur disebabkan kelembaban ruang perpustakaan, yang berupa rembesan air hujan dari atap ruang perpustakaan.

3) Koleksi yang mengeriting
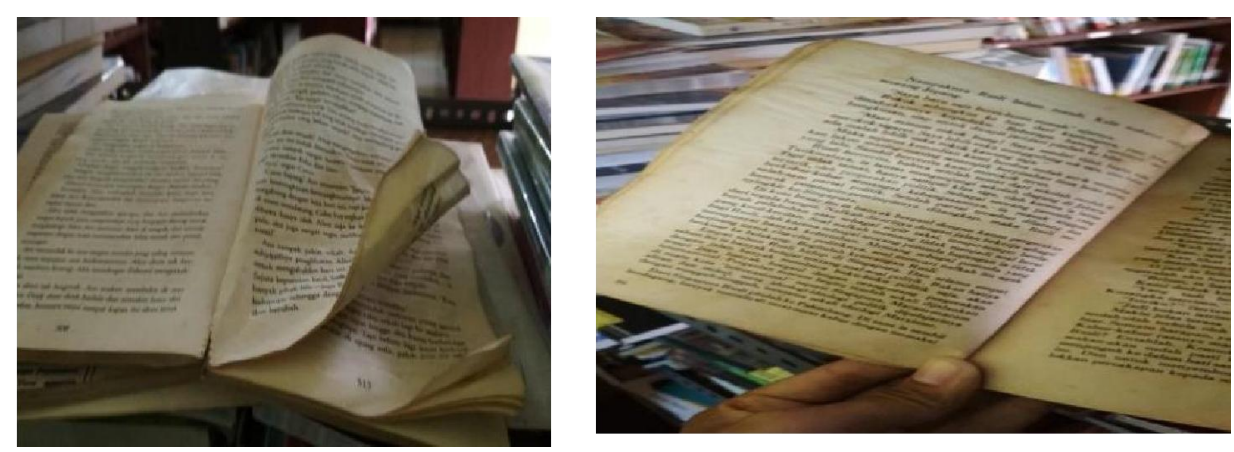

Gambar 5. Koleksi yang mengeriting

Koleksi mengeriting disebabkan terkena sinar matahari secara langsung dalam waktu lama. Hal ini terjadi karena tirai (vertical blind) belum sepenuhnya menutupi jendela di ruang perpustakaan.

4) Koleksi yang berdebu
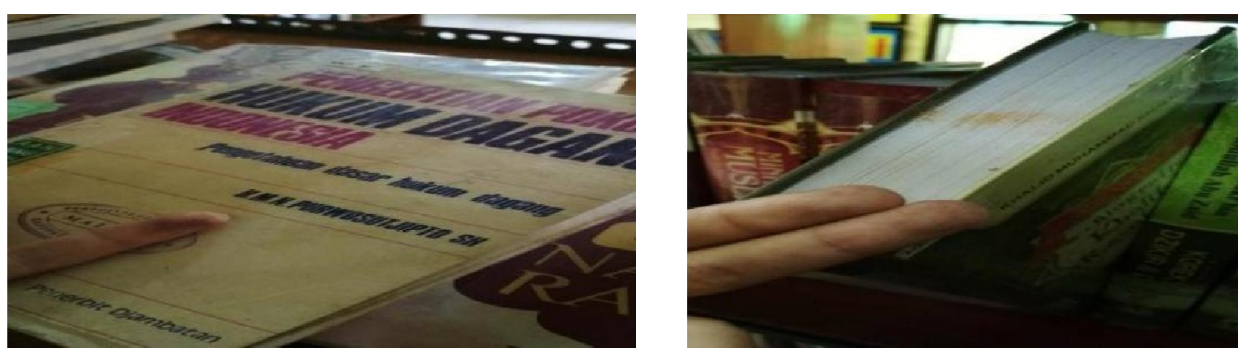

Gambar 6. Koleksi yang berdebu 
Koleksi berdebu disebabkan sebagian jendela yang terbuka dan lokasi perpustakaan yang dekat dengan jalan raya sehingga mengakibatkan banyaknya debu yang masuk ke ruang perpustakaan dan menempel di koleksi.

5) Koleksi yang terkena serangga
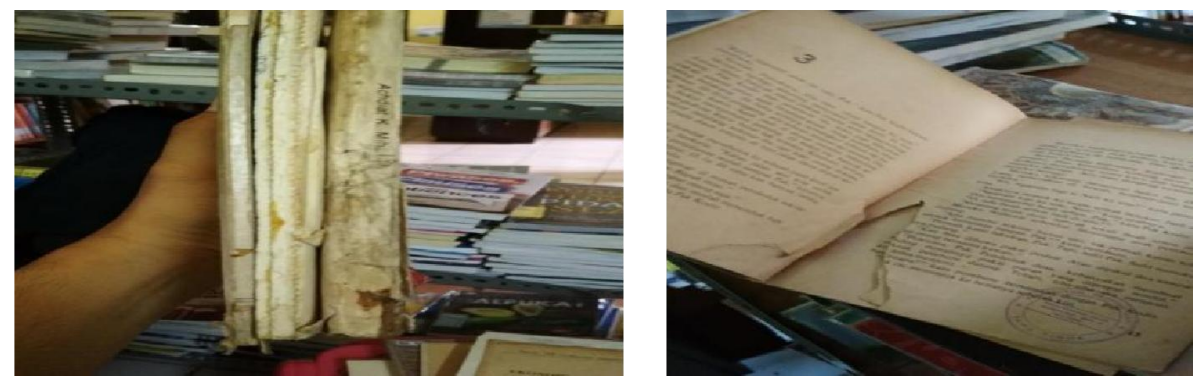

Gambar 7. Koleksi yang terkena serangga

Koleksi yang terkena gigitan serangga disebabkan suhu ruangan yang lembab, sehingga memicu berkembangnya serangga yang dapat merusak koleksi.

6) Koleksi jilidan terlepas
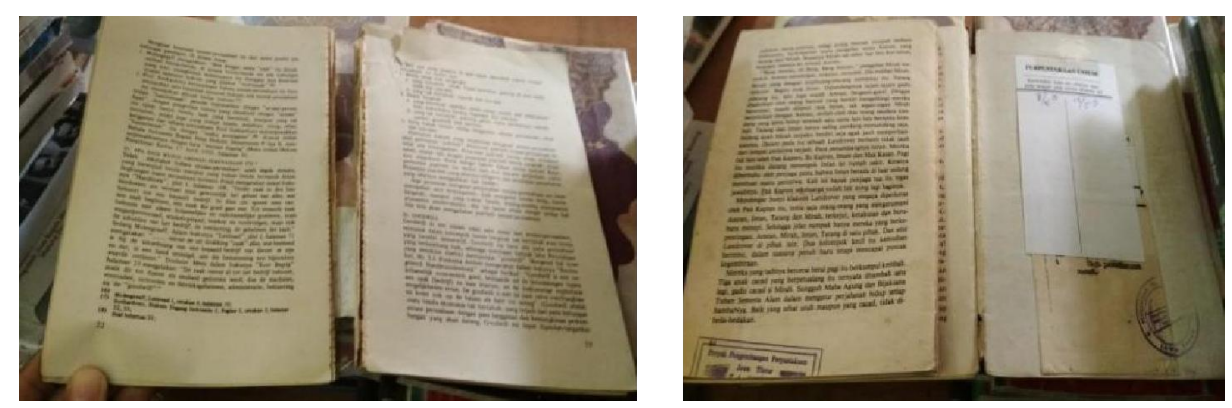

Gambar 8. Koleksi jilidan terlepas

Koleksi yang jilidannya lepas disebabkan oleh umur koleksi yang sudah tua dan kondisi ruangan yang lembab.

\subsection{Analisis Faktor Fisika}

1) Debu

Debu yang masuk ke ruangan koleksi bahan bacaan umum melalui jendela, tepatnya pada atas rak koleksi. Tidak semua jendela di atas rak koleksi ruang koleksi perpustakaan tertutup rapat (Gambar 9). Jendela yang terbuka membuat udara dan debu dari luar masuk ke ruang koleksi dan akhirnya menempel kesemua tempat yang ada di perpustakaan. Debu yang menempel pada koleksi ditunjukkan oleh Gambar 10. 

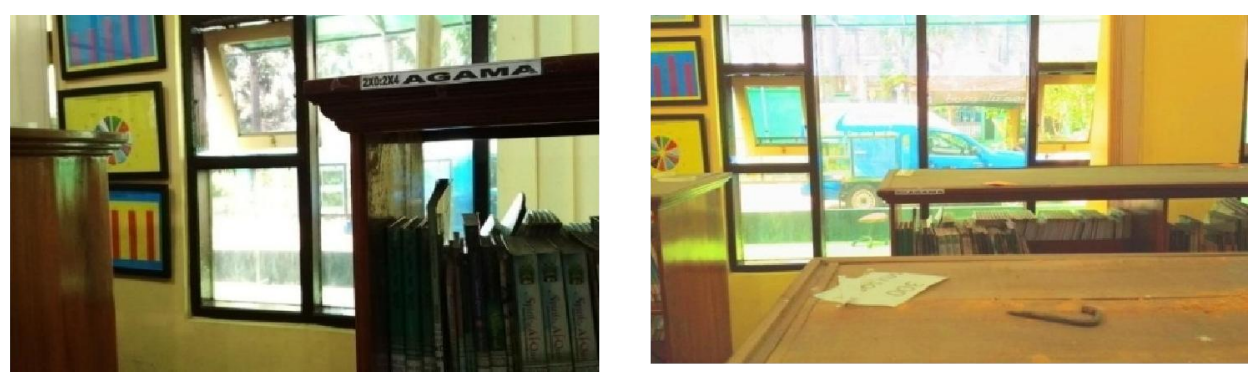

Gambar 9. Jendela yang terbuka
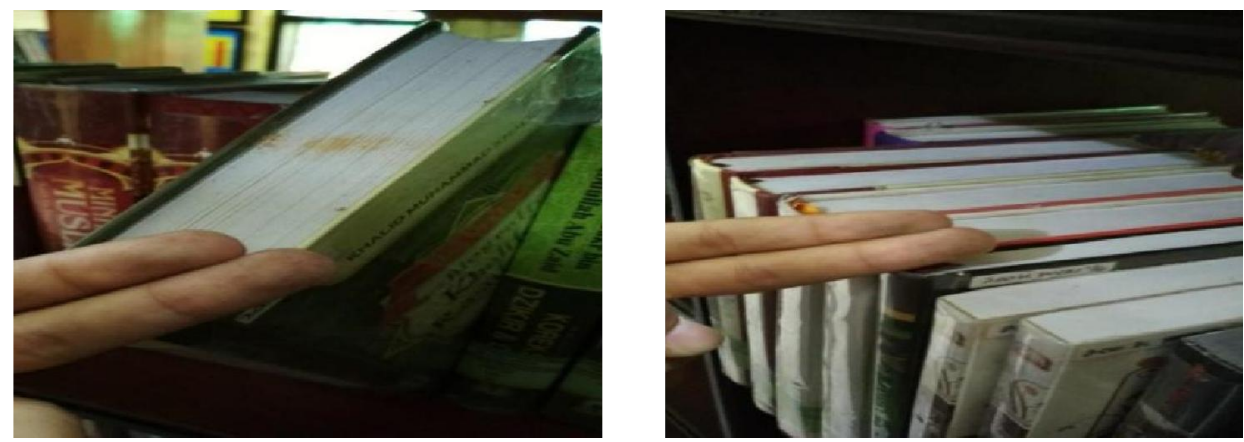

Gambar 10. Debu yang menempel pada koleksi

Debu di koleksi dibersihkan dengan kuas dan vacuum cleaner. Masalahnya adalah pembersihan debu pada koleksi dengan kuas tidak dilakukan secara rutin, dan pembersihan menggunakan debu dengan vacuum cleaner hanya dilakukan satu kali dalam sebulan.

2) Cahaya

Cahaya yang ada dalam ruangan penyimpanan koleksi bersumber dari sinar matahari dan lampu. Arah cahaya matahari yang masuk ke ruang koleksi ditujukkan Gambar 11.

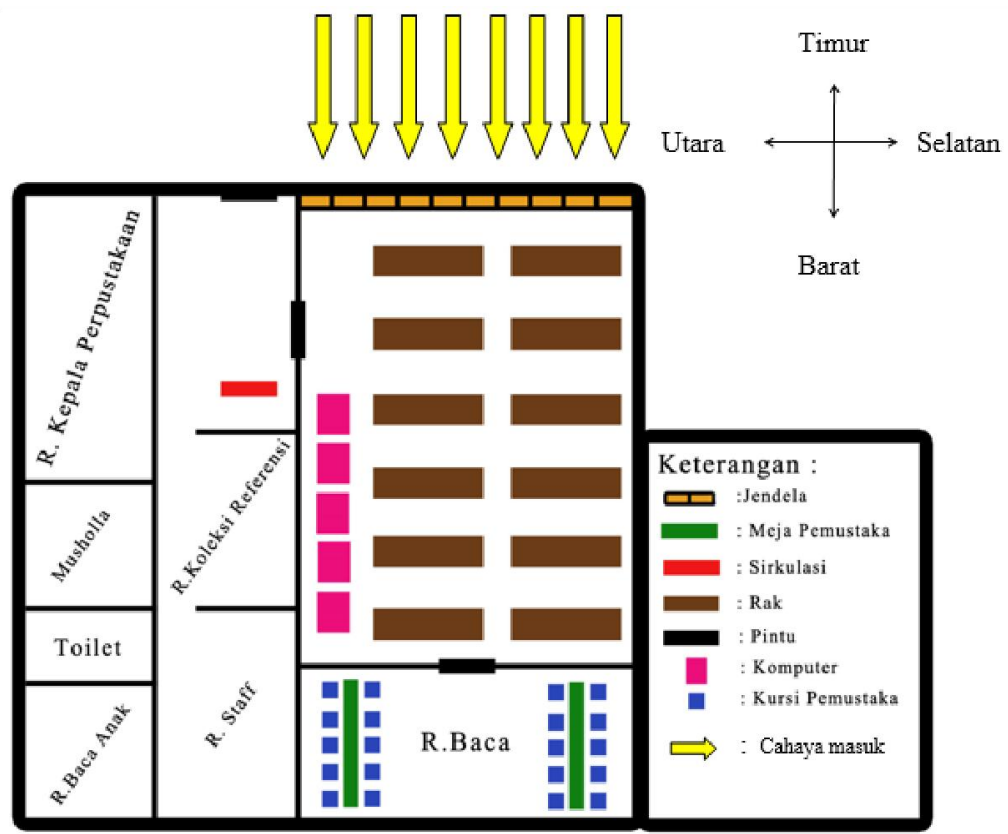

Gambar 11. Arah cahaya matahari 
Cahaya matahari masuk jendela melalui sisi timur gedung dan langsung mengenai koleksi, Walaupun terdapat tirai pada jendela, namun tirai terbuka - menyebabkan sinar matahari masuk ke dalam ruangan dan mengenai koleksi secara langsung sehingga koleksi mengeriting (Gambar 5).

3) Suhu dan kelembaban

Pengukuran suhu dan kelembaban dilakukan pada pagi sampai malam hari selama 7 hari. Pengukuran dilakukan setiap 5 menit. Gambar 12 menunjukkan hasil pengukuran suhu secara keseluruhan. Pada pagi hari rata-rata suhunya sekitar $27,4^{\circ} \mathrm{C}$, siang dan sore suhunya sekitar 28,6 dan $28,9^{\circ} \mathrm{C}$, pada malam hari suhunya sekitar $24,6^{\circ} \mathrm{C}$. Rata-rata suhu harian sekitar $27,4^{\circ} \mathrm{C}$ (Gambar 12).

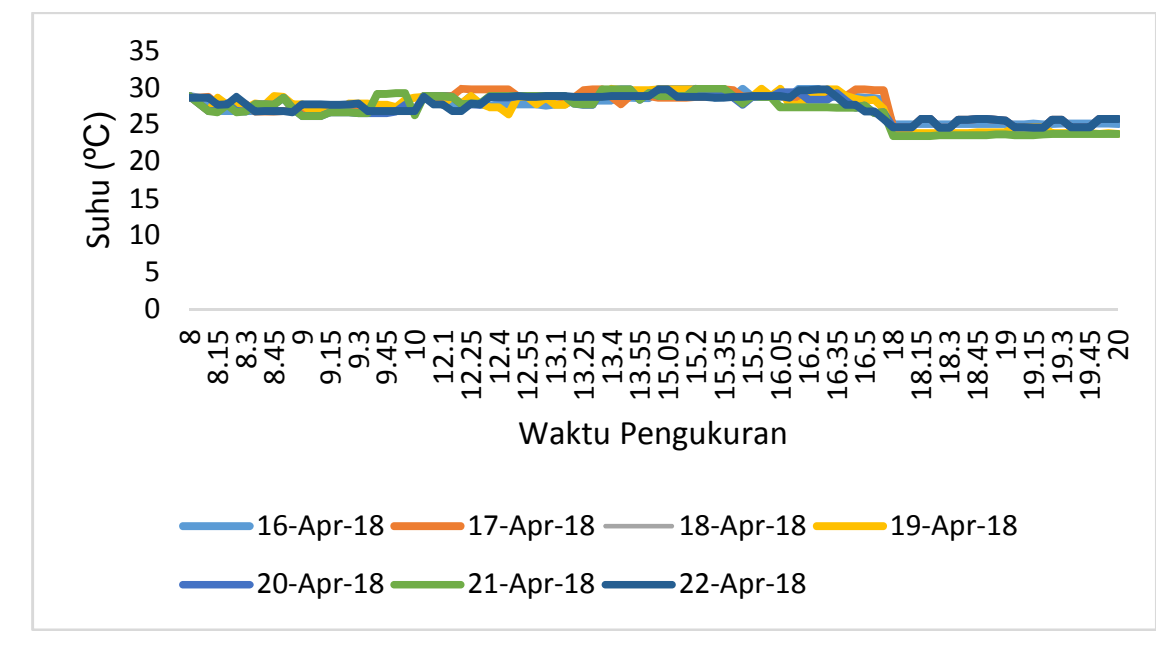

Gambar 12. Hasil pengukuran suhu di ruang koleksi

Menurut UU No.43 Tahun 2007, suhu ruang koleksi perpustakaan sebaiknya antara $19^{\circ} \mathrm{C}$ $23^{\circ} \mathrm{C}$. Suhu harian penyimpanan ruangan koleksi lebih tinggi dibandingkan suhu yang dipersyaratkan, sehingga ruangan terasa panas dan membuat koleksi menjadi kering dan mengeriting. Apabila suhu ruangan tidak dikontrol maka akan membuat koleksi yang ada menjadi rusak dan tidak dapat dimanfaatkan oleh pemustaka.

Berdasarkan hasil pengukuran kelembaban yang ditunjukkan oleh Gambar 13 diketahui bahwa rata-rata kelembaban pada pagi, siang, sore, dan malam hari sekitar $67 \%$, 68\%, $65 \%$, dan $61 \%$ RH. Rata-rata hasil pengukuran tersebut sekitar $65 \%$ RH. Kelembaban tersebut memiliki nilai yang lebih tinggi dibandingkan dengan kelembaban yang dipersyaratkan oleh UU No.43 Tahun 2007 yakni sekitar 40-50\%RH. 


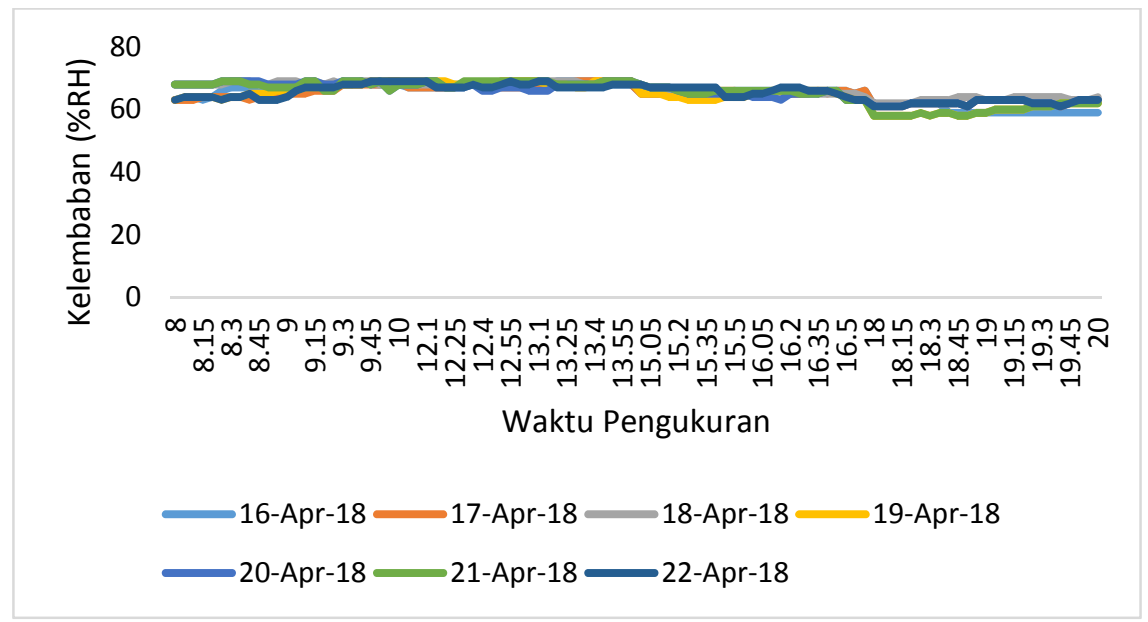

Gambar 13. Hasil pengukuran kelembaban di ruang koleksi

Tingginya kelembaban ruangan di Perpustakaan Umum Kabupaten Malang menunjukkan tingginya kadar uap air sehingga menyebabkan banyak koleksi yang berjamur. Selain itu, kelembaban yang tinggi dan ruangan yang kurang bersih menjadi tempat hidup dan berkembangnya binatang pengerat (tikus) dan serangga, yang dapat mengancam kerusakan koleksi.

\section{KESIMPULAN}

Faktor fisika yang berpengaruh terhadap kondisi koleksi di Perpustakaan Umum Kabupaten Malang yaitu suhu dan kelembaban, debu, dan cahaya. Pengukuran suhu menunjukkan rata-ratanya adalah $27,4^{\circ} \mathrm{C}$ sedangkan pengukuran rata-rata kelembaban yaitu $65 \%$ RH. Koleksi di perpustakaan banyak yang berdebu dan terkena sinar matahari secara langsung sehingga menyebabkan koleksi kering dan mengeriting. Dari pengukuran dan pengamatan faktor fisika menunjukkan bahwa baik suhu, kelembaban, debu dan cahaya pada Perpustakaan Umum Kabupaten Malang belum menunjukkan kondisi yang ideal. Untuk menjaga kondisi koleksi pada Perpustakaan Umum Kabupaten Malang diperlukan adanya monitoring rutin terkait faktor fisika diantaranya debu, cahaya, suhu dan kelembaban dan memberikan penambahan peralatan untuk mengontrol faktor tersebut berada pada kondisi ideal. 


\section{DAFTAR PUSTAKA}

Alahudin, M. 2014. Pengaruh Termal dalam Ruangan Perpustakaan Terhadap Kondisi Buku dan Kenyamanan Pembaca (Studi Kasus Perpustakaan Universitas Musamus Merauke), 2(17).

Bahri, S. 2015. Pembuatan Pulp dari Batang Pisang.

CV Java Multi Mandiri. 2019. Thermo Hygro (Alat Pengukur Suhu Udara dan Kelembaban). https://digital-meter-indonesia.com/thermo-hygro-alat-pengukur-suhu-udara-dan-kelembaban/.

Darmono. 2001. Manajemen dan Tata Kerja Perpustakaan Sekolah. Jakarta: Grasindo.

Dureau, J.M. \& Clements, D.W.G. 1990. Dasar-Dasar Pelestarian dan Pengawetan Bahan Pustaka. Jakarta: Perpustakaan Nasional RI.

Fatmawati, E. 2017. Identifikasi Faktor-Faktor Penyebab Kerusakan Koleksi Perpustakaan, 7(7), $108-19$.

Makarim, L. \& Ramdhan, M. 2014. Pedoman Teknis Layanan Perpustakaan dan Informasi. Jakarta: Perpustakaan Nasional RI.

Martoatmodjo, K. 2014. Pelayanan Bahan Pustaka. Jakarta: Universitas Terbuka.

Razak, M., Anggraini, R., \& Supriyanto, S. 1992. Pelestarian Bahan Pustaka dan Arsip. Jakarta.

Riyadi, A. 2014. Menilai Kondisi Bahan Pustaka Perpustakaan Melalui Pemetaan Konservasi. https://www.perpusnas.go.id/magazine-detail.php?lang=id\&id=8336.

Soraya, A. \& Damayanti, L. 2015. Pelestarian Bahan Pustaka: Bahan Ajar Diklat Calon Pustakawan Tingkat Ahli. Jakarta: Pustaka Nasional RI.

Teygeler, R., Bruin, Gd., Wassink, B., \& Zanen, B.V. 2001. Preservation of Archives in Tropical Climates: An Annotated Bibliography. Paris: The Hague.

Undang-Undang Republik Indonesia Nomor 43 Tahun 2007 Tentang Perpustakaan. Jakarta. 